\title{
THE EFFECT OF THE MARKETING MIX ON CUSTOMER SATISFACTION IN BUILDING CUSTOMER LOYALTY: A CASE STUDY OF PT PUPUK SRIWIDJAJA
}

\author{
Setiadi Aditya*, Daryanto Arief, Fahmi Idqan \\ Business School, Bogor Agricultural University, Indonesia \\ *E-mail: adityasetiadi51@gmail.com
}

\begin{abstract}
Sales decline is caused by low customer loyalty that makes customers to quickly switch to other products. This research aimed to analyze the performance of marketing mix, the level of customer satisfaction and loyalty, and the factors of marketing mix that affected customer satisfaction and loyalty, as well as to formulate strategies that could be performed to improve customer satisfaction and loyalty. This research applied Structural Equation Modeling method. Based on the analysis results of the factors affecting purchase decision to PT PUSRI fertilizer, it could be concluded that the level of customer satisfaction of PT PUSRI fertilizer was in the 'satisfied' category with the value of 67.8 percent, while the level of customer loyalty of PT PUSRI fertilizer was in the 'loyal' category with the value of 64.51 percent. Factors of the marketing mix that significantly affected customer satisfaction to PT PUSRI fertilizer were product and price, while place and promotion factors significantly did not affect it. Customer satisfaction significantly affected the building of customer loyalty. The strategy that could be applied for product variable was differentiation of aesthetic quality and for price variable was low-cost leader pricing.
\end{abstract}

\section{KEY WORDS}

Fertilizer, loyalty, marketing mix, satisfaction.

Indonesia is an agrarian country, a country where most of the population works in agriculture. Agriculture has a very important role in the economic sector, the fulfillment of the need for food and agricultural sector in which it contributes significantly to the labor recruitment. The agricultural sector contributes substantially to economic growth in Indonesia. Based on data from the Central Bureau of Statistics (2015), agriculture is the third largest sector, in the total of Gross Domestic Product (GDP) after the industry and trade sectors, that contributes as many as $13.38 \%$.

One of the agricultural sectors affecting the country's income is agribusiness. Agribusiness is defined as the overall production and distribution activities of farming production facilities, farming production activities, storage activities, processing activities, and distribution of agricultural commodities (Sudana, 2005). The development of agribusiness sector towards Indonesia's economic growth is inseparable from supporting industries that support the advancement of the agricultural sector. One of the supporting industries comes from the agribusiness sub-sector, namely the fertilizer industry. Pranitit (2016) mentioned that fertilizer is utilized as a source of nutrients to meet the nutritional needs of plants and improve soil structure. The provision of fertilizer in the planting media can increase the nutrient content and fertility.

A lot of companies engaged in fertilizer industry shows that the competition for fertilizer business starts to increase. The increasing contribution of agribusiness to Indonesia's economic growth is accompanied by the increasing of Indonesia's agricultural production. It also affects the increasing needs for fertilizer that must be met. Indonesia established the first fertilizer company named Pupuk Sriwidjaja (PUSRI).

PUSRI is a company established as a pioneer of urea fertilizer producer in Indonesia on December 24, 1959 in Palembang South Sumatra, under the name of PT Pupuk Sriwidjaja (Persero). The long history of PUSRI as the pioneer of national fertilizer producers for more than 50 years has proven its ability and commitment in performing the important tasks given by the government. PT PUSRI began to get new competitors from China in 2000. 
For 10 years, the importation of Chinese fertilizer was still relatively small at around 300,000 400,000 tons/year. The importation of fertilizer experienced a very high increase in 2010 to the present. The high importation of Chinese fertilizer affected the sales decline at PT PUSRI but it turned out that there were national fertilizer companies that could withstand the onslaught of Chinese fertilizer import. It could be seen from the sales of PT Petro Kimia and PT Pupuk Kaltim that experienced no sales decline (Figure 1).

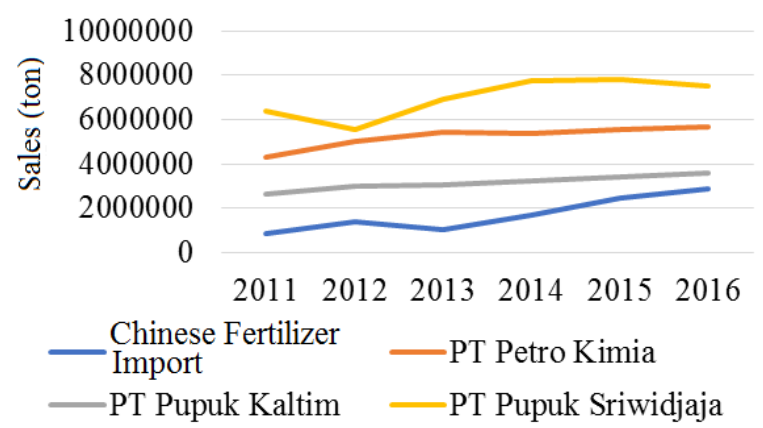

Figure 1 - Chinese Fertilizer Import Chart, Fertilizer Sales of PT Pupuk Kaltim, and Fertilizer Sales of PT Pupuk Sriwidjaja in 2011-2016

In tight competitive conditions, finding new customers requires greater cost and time than maintaining the existing customers. The company spends five times greater on finding new customers rather than maintaining the existing ones (Kotler and Keller 2009; Wills 2009). One of the switching barriers that can be performed to maintain the customers is by building or growing customer loyalty.

Loyalty is a voluntary commitment that may occurs when a customer is loyal to a product, even when they have the opportunity to switch to other products at any time. The increasing customer loyalty will increase customer retention (Schiffman \& Kanuk 1997). It is mentioned that the better the customer retention by the management, the greater the number of customers and profits. Loyal customers have advantages and give benefits to the profit growth of the company (Raphel et al., 2007).

Customer loyalty can be built from the satisfaction they feel (Zeithaml and Bitner 2000). Customer satisfaction and customer loyalty, within its process, are affected by the performance of marketing mix. The performance of marketing mix is a reflection of the performance of the company. The marketing mix that is able to satisfy the customers has the potential to lead to long-term and short-term sales growth, as well as repurchasing (Kotler and Keller 2009). Therefore, a company must be able to manage the elements of the marketing mix through strategy steps and evaluate the performance of marketing mix in order to maintain the customers from switching to other competitor companies.

Research Problem. PT PUSRI sets the sales target as the indicator of business success. This sales target is based on the company's productivity and sales from the previous years, so the sales target that had been set will always increase every year. However, the high level of competition has made it difficult for PT PUSRI in achieving the predetermined sales target. Moreover, PT PUSRI experienced sales decline in 2015.

As a company engaged in the field of agribusiness, the management of PT PUSRI is required to understand the importance of customers for the sustainability of the company. In running the business, the management should be customer oriented in order to survive the competitive level of business competition and should increase the sales in order to achieve the predetermined target. One effort that can be performed by the management of PT PUSRI is to grow the sense of loyalty in their customers. Loyal customers are the company's greatest asset because they will re-visit, buy more, and recommend the company's products to others without additional promotional costs. Growing customer loyalty does not only retain the existing customers but also open the opportunities to attract the new customers. It may affect the increase in sales which will increase the profitability of the company. 
The company needs to focus on what factors affecting customer loyalty and how to improve or enhance the factors affecting this matter. In its creation, loyalty is affected by customer satisfaction that is also affected by marketing mix. The dimensions in the marketing mix affect customer loyalty through customer satisfaction indirectly.

If the customer perception on the actual performance of the company is higher than what they expect, customers who have a positive experience will keep that experience in their memories. If the customers at any time require the product, then they will remember the products that had provided positive experience for themselves, and repurchase the product that had given them the sense of satisfaction.

This sales decline is a serious problem for the company. This fierce business competition requires PT PUSRI to improve its marketing strategy as soon as possible. The company should know what factors affecting customer's decision in buying the fertilizer.

Based on the problems that have been described above, the following problems can be formulated:

- How is the performance of marketing mix of PT Pupuk Sriwidjaja?

- How is the level of customer satisfaction and loyalty to the fertilizer of PT Pupuk Sriwidjaja?

- What are the factors of marketing mix that affect customer satisfaction and loyalty?

- What are the strategies that can be conducted to improve customer satisfaction and loyalty to the fertilizer of PT Pupuk Sriwidjaja?

Research Objectives. Based on the research problems that have been mentioned above, the objectives of the research are the following:

- Analyzing the performance of marketing mix of PT Pupuk Sriwidjaja;

- Analyzing the level of customer satisfaction and loyalty to the fertilizer of PT Pupuk Sriwidjaja;

- Analyzing the factors of marketing mix that affect customer satisfaction and loyalty;

- Formulating the strategies that can be conducted to improve customer satisfaction and loyalty to the fertilizer of PT Pupuk Sriwidjaja.

Significance of the Research. This research is expected to be an input for PT PUSRI as a consideration in determining the policy of an effective company marketing strategy. The significance of this research for researchers is as a means of improving self-competence, both in terms of knowledge and skills in analyzing production efficiency.

Scope of the Research. This research described the factors determining customer satisfaction and loyalty to the purchase of PT PUSRI fertilizer. The analyzed factors consist of product, price, place, promotion, customer satisfaction, and customer loyalty. The research object was PT PUSRI fertilizer which was well known by the customer. The criterion of respondents in this research was farmers who use non-subsidized fertilizer from PT PUSRI in the distribution area that experienced the most severe sales decline; the area of South Sumatera. South Sumatera was chosen because it was the main marketing area of PT PUSRI.

\section{METHODS OF RESEARCH}

Setting, Time and Research Approach. Based on the obtained information, it was known that the worst sales decline in South Sumatra was in Tanjung Lago District and Mekar Sari District of Banyuasin of South Sumatra. This research was conducted for six months starting from December 2017 until April 2018. The approach used in this research was quantitative approach by using survey method involving respondents from the level of farmers.

Types and Sources of the Data. The type of data used in this research was primary data that were coming from inside and outside of the company. The primary data were obtained through observation, focus group discussion, and interview that were conducted directly to internal and external sources. The secondary data were obtained from literature study. 
Respondent Determination Method. The sample collecting technique of the research was based on non-probability sampling method involving convenience sampling technique. According to Sumarwan et al. (2015), non-probability sampling, in the sample determination, does not require an opportunity so that the generated data are only applied to the persons who become the research respondents. Convenience sampling was chosen based on consideration of ease in obtaining the data required by the researcher. According to Sumarwan et al. (2015), one of the reasons for the popularity of this technique is that the researcher can do the research in easy-to-find crowded places.

All respondents filled out the questionnaires voluntarily without any coercion. The criteria of the respondents are:

- Ever used PT PUSRI fertilizer in the last 6 months;

- Purchase PT PUSRI fertilizer through authorized distributor.

Conceptual Framework. Based on the empirical studies that had been performed, the dimensions of marketing mix (4P) were assumed to affect customer satisfaction. In addition, customer satisfaction was assumed to affect loyalty. Conceptually, the framework of this research can be seen in Figure 1 below.

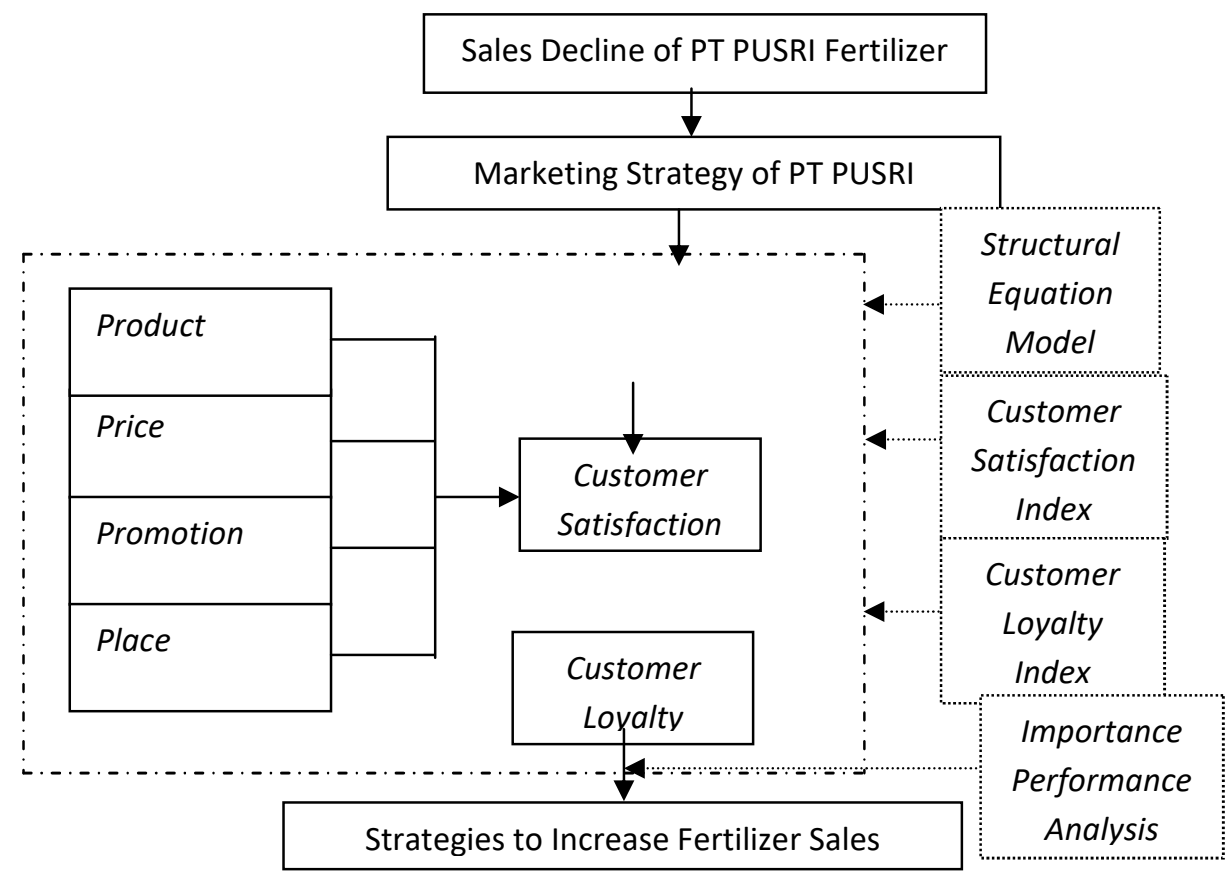

Figure1 - Conceptual Framework

Research Hypotheses. Based on the conceptual framework above, the hypotheses to be tested in this research are:

- H1: Product has positive and significant effect on satisfaction;

- H2: Price has positive and significant effect on satisfaction;

- H3: Place has positive and significant effect on satisfaction;

- H4: Promotion has positive and significant effect on satisfaction;

- H5: Satisfaction has positive and significant effect on loyalty.

Data Analysis and Processing Technique. The data processing of the research was performed with some analyses. The data analyzes were Customer Satisfaction Index (CSI), Customer Loyalty Index (CLI), Structural Equation Model (SEM), and Importance Performance Analysis (IPA). 


\section{RESULTS AND DISCUSSION}

Performance Level of Marketing Mix. Factors determining marketing mix on customer satisfaction and loyalty consisted of Product, Price, Place, and Promotion. Each factor that was assumed to affect the interest of customer behavior contained the variable of assessment indicator.

The performance level of the indicator variables in each factor was determined through frequency analysis in the form of a percentage of the results of the customer assessment of the statement or the indicator variable on each of these factors. The assessment was carried out by using Likert scale $1-5(1=$ strongly disagree to $5=$ strongly agree $)$. The number of respondents $(n)$ in this research was 110 people. Descriptive statistics on the research variables were used to provide an overview of the responses from the respondents to the research variables. The analysis of descriptive statistics was conducted on 110 respondents to be further processed. Descriptive statistics from the respondents' answers would be explained per indicator of each variable. Table 1 showed the number of respondents $(n)$, mean value, minimum value, and maximum value. The mean score indicated the average values of the respondents' answers. The median value is the mid value of the data whose magnitude had been ordered in sequence. The maximum and minimum values described the answers to the question items selected by the respondents in the questionnaire.

Table 1 - Descriptive Statistics of the Variables

\begin{tabular}{|c|c|c|c|c|}
\hline Constructs & Indicators & Mean & Min & Max \\
\hline \multirow[t]{4}{*}{ Product } & X11 & 3.97 & 1 & 5 \\
\hline & X12 & 3.91 & 1 & 5 \\
\hline & X13 & 3.91 & 1 & 5 \\
\hline & X14 & 3.74 & 1 & 5 \\
\hline \multirow[t]{3}{*}{ Price } & X21 & 3.52 & 1 & 5 \\
\hline & $\times 22$ & 3.56 & 1 & 5 \\
\hline & $\times 23$ & 3.22 & 1 & 5 \\
\hline \multirow[t]{2}{*}{ Place } & X31 & 3.43 & 1 & 5 \\
\hline & X32 & 3.1 & 1 & 5 \\
\hline \multirow[t]{3}{*}{ Promotion } & $\overline{X 41}$ & 2.85 & 1 & 5 \\
\hline & $\times 42$ & 2.98 & 1 & 5 \\
\hline & $\times 43$ & 2.6 & 1 & 5 \\
\hline
\end{tabular}

Factors Affecting Satisfaction and Loyalty:

Evaluation of Model Fit Level. According to Hair et al. (1995), fit evaluation was performed through several stages, namely 1) overall model fit, 2) measurement model fit, and 3) structural fit model. The evaluation stage was aimed to see how the fit level of the original data (in the field) matched the designed model.

Based on the evaluation of the overall model fit, this model was considered to have met the requirements and was classified as good fit so that the research model was considered to be feasible. Based on the measurement model fit test, the attributes contained in the model were valid because they had standardized loading factor (SLF) value $\geq 0.5$. The indicators of $X_{31}, X_{41}$, and $Y_{22}$ were removed from the model. The reason was that the t-count values in all three indicators in the initial model were less than 1.96. The final SEM measurement model can be seen in Figure 2 below.

The Contribution of Dimensions to Variables. The product variable had four indicators. These indicators are features, reliability, performance, and durability. These four indicators had higher t-count values than t-tables (1.96), so it could be considered that these four indicators had a significant contribution to the product variable. The four indicators were sufficiently feasible to reflect the product variables in this research because it had loading factor value of $0.62,0.75,0.81$, and 0.78 (Table 2 ).

The price variable had three indicators. All three indicators were match-to-quality price, competitive price, and affordable price. All three indicators had t-count values greater than ttable that were respectively $3.91,17.94$, and 3.78 . These findings indicated that these three 
indicators contributed significantly to the price variable. In addition, these three indicators had positive and different loading factor value of $0.7,0.96$, and 0.68 . The indicator that had the highest loading factor value was the competitive price.

The customer satisfaction variable had two indicators. The two indicators were overall satisfaction and harvest yields. The two indicators almost had the same loading factor value of 0.81 and 0.78 . This indicated that both indicators had almost equal contribution in reflecting satisfaction variable. Similar findings were also obtained from a research conducted by Iskandar AYS (2017) using the overall satisfaction indicator.

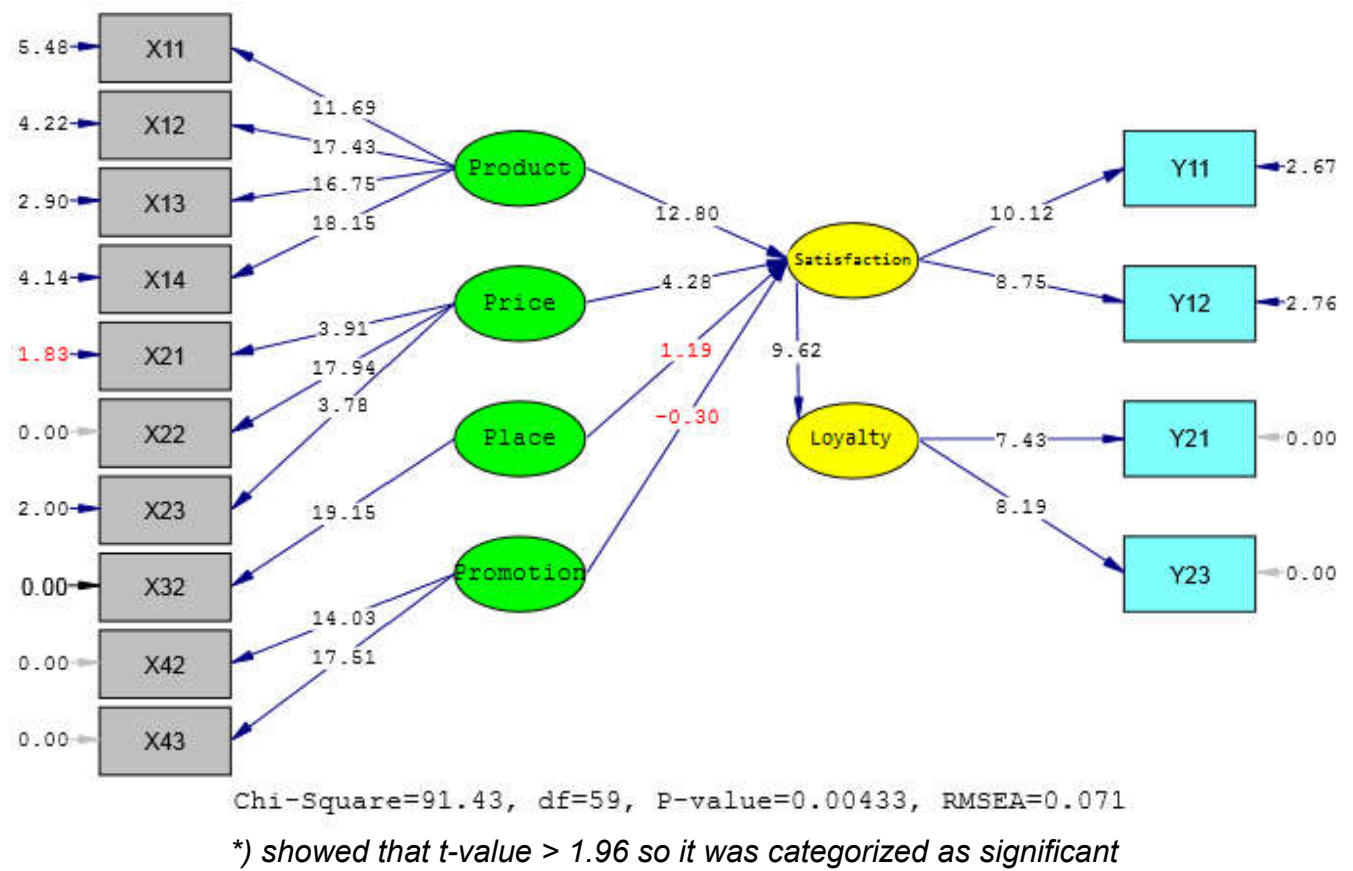

Figure 2 - SEM Measurement Model

The loyalty variable had three indicators. The three indicators were referrals, repurchases, and retention. Among the three indicators, the retention indicator had a t-value $<1.96$ at 1.56 (Table 2) so that the indicator must be removed from the model. Therefore, in this variable there were only two indicators that could describe the loyalty variable namely repurchase and referrals.

Table 2 - t-count and Loading Factor Values on the Indicators of Product, Price, and Satisfaction Variables

\begin{tabular}{llll}
\hline Variables & Indicators & Loading Factor & t-count \\
\hline Product & Features & 0.62 & 11.69 \\
& Reliability & 0.75 & 17.43 \\
& Performance & 0.81 & 16.75 \\
& Durability & 0.78 & 18.15 \\
\hline Price & Match-to-quality Price & 0.7 & 3.91 \\
& Competitive Price & 0.96 & 17.94 \\
& Affordable Price & 0.68 & 3.78 \\
\hline Satisfaction & Overall Satisfaction & 0.81 & 10.12 \\
& Harvest Yields & 0.78 & 8.75 \\
\hline Loyalty & Repurchase & 0.94 & 7.43 \\
& Referrals & 0.97 & 9.19 \\
\hline
\end{tabular}

Research Hypotheses Testing. The effect of dimension in marketing mix on customer satisfaction could be seen from the construct coefficient value and the t-count value. Based on the findings of the research, from the four marketing mix variables, there were only two marketing mix variables that had t-count values greater than t-table (1.96). Both variables 
were product and price which had t-count values respectively 12.80 and 4.28 (Table 3). These values indicated that both variables significantly affected customer satisfaction. However, not all marketing mix variables had significant effect on customer satisfaction. Place and promotion variables had smaller t-count values than t-table (Table 3). It meant that these two variables significantly had no effect on satisfaction.

The satisfaction variable itself had a t-count value greater than t-table. It meant that satisfaction significantly affected loyalty. Marketing mix had a weak direct effect in affecting loyalty, so customer satisfaction was required as the intervening variable to see the effect of marketing mix on loyalty indirectly (Cengiz \& Yayla, 2007; Muala \& Qurneh, 2012; Pyeong et al., 2014). The findings of previous research also suggested that a positive construct coefficient indicated that increasing customer satisfaction would increase the loyalty of the customer and they would tend to behave in a favorable way to the company (Semuel 2006; Oghojafor et al., 2014).

Table 3 - Results of SEM Model Estimation

\begin{tabular}{lllllll}
\hline \multicolumn{2}{l}{ The Effect of the Variables } & & Loading Factor & t-count & Conclusion & Description \\
\hline 1. $\mathrm{H}_{1}:$ Product & $\rightarrow$ & Satisfaction & 0.77 & 11.27 & Significant & Accept $\mathrm{H}_{1}$ \\
2. $\mathrm{H}_{2}:$ Price & $\rightarrow$ & Satisfaction & 0.21 & 1.73 & Significant & Accept $\mathrm{H}_{2}$ \\
3. $\mathrm{H}_{3}:$ Place & $\rightarrow$ & Satisfaction & 0.07 & 15.47 & Not Significant & Reject $\mathrm{H}_{3}$ \\
4. $\mathrm{H}_{4}:$ Promotion & $\rightarrow$ & Satisfaction & -0.01 & 11.25 & Not Significant & Reject $\mathrm{H}_{4}$ \\
5. $\mathrm{H}_{5}:$ Satisfaction & $\rightarrow$ & Loyalty & 0.76 & 3.56 & Significant & Accept $\mathrm{H}_{5}$ \\
\hline
\end{tabular}

Note: *) significant t-count $>$ t-table (1.96).

Customer Satisfaction Index. The overall CSI value was obtained by the total sum of the CSI values per indicator. The total CSI value of PT PUSRI fertilizer customers was 67.80 percent. This value was in the range of values $0.60-0.80$ or $60 \%<x \leq 80 \%$, which belonged to the "satisfied" category. The calculation of CSI values could be seen in Table 4 below.

Table 4 - Calculation Result of Customer Satisfaction Index of PT PUSRI Fertilizer

\begin{tabular}{lllllll}
\hline Indicators & Loading Factor & Coefficient Construct & Effect & Volume & CSI \% & CSI Per Indicator \\
\hline Features & 0.64 & 0.8 & 0.53 & 0.19 & 72.73 & 13.6 \\
Reliability & 0.74 & 0.8 & 0.61 & 0.22 & 73.64 & 15.93 \\
Performance & 0.66 & 0.8 & 0.55 & 0.19 & 71.82 & 13.85 \\
Durability & 0.73 & 0.8 & 0.61 & 0.21 & 63.64 & 13.58 \\
Match-to-quality Price & 0.72 & 0.2 & 0.14 & 0.05 & 58.18 & 2.95 \\
Competitive Price & 0.96 & 0.2 & 0.19 & 0.07 & 62.73 & 4.24 \\
Affordable Price & 0.68 & 0.2 & 0.14 & 0.05 & 50.91 & 2.44 \\
Building & 1 & 0.1 & 0.06 & 0.02 & 45.45 & 0.96 \\
Promotional Quantity & 0.87 & 0 & 0.01 & 0 & 41.82 & 0.13 \\
Purchase Bonus & 0.96 & 0 & 0.01 & 0 & 34.55 & 0.12 \\
Total & & & 2.84 & & & \\
CSI & & & & & & 67.8 \\
\hline
\end{tabular}

Customer Loyalty Index. The result of the calculation yielded the overall CLI value. The CLI value of PT PUSRI fertilizer customers was 64.50 percent (Table 5). This value was in the range of $0.60-0.80$ or $60 \%<x \leq 80 \%$. It meant that the customer loyalty index of PT PUSRI fertilizer was in the criteria of "loyal".

Table 5 - Calculation Result of Customer Loyalty Index of PT PUSRI Fertilizer

\begin{tabular}{llllll}
\hline Indicators & Loading Factor & Effect & Volume & CLI \% & CLI per Indicator \\
\hline Repurchase & 0.94 & 0.94 & 0.49 & 40.91 & 20.13 \\
Referrals & 0.97 & 0.97 & 0.51 & 80.91 & 41.09 \\
Total & & 1.91 & & & 61.22 \\
CLI & & & & 64.51 \\
\hline
\end{tabular}




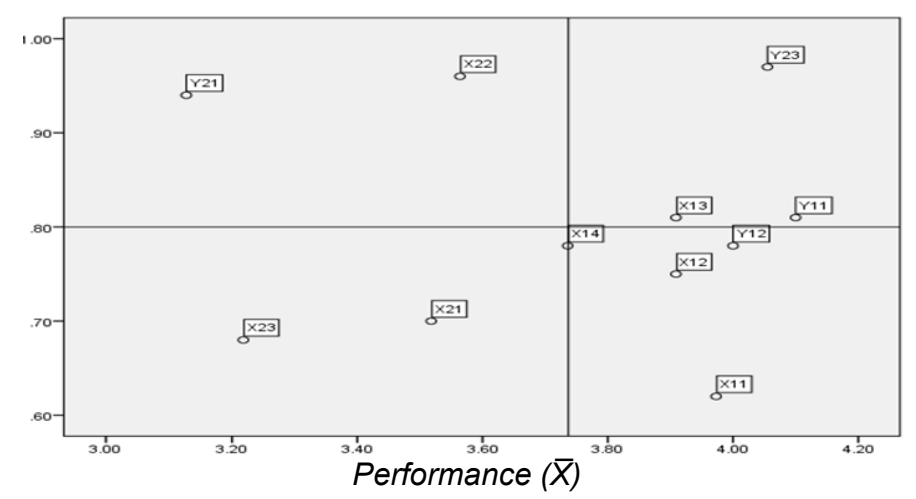

Figure 3 - IPA Diagram of the Customer of PT PUSRI Fertilizer

Based on the results of the IPA diagram evaluation, the order of priority level of improvement that PT PUSRI should perform was (1) Competitive Price, (2) Performance, (3) Match-to-Quality Price, (4) Affordable Price, (5) Features, (6) Reliability, and (7) Durability.

Strategies to Increase the Sales. The research obtained some findings which would then be compiled into managerial implications that were beneficial for PT PUSRI. The performance of PT PUSRI marketing mix was still below the average. It meant that all the performance of the variables at PT PUSRI could still be improved. After obtaining the results from SEM analysis, there were only 2 variables that had significant effect, those were product and price. The priority strategy from the indicators of these two variables would be ordered by using IPA analysis.

Based on the results of IPA analysis, there was an indicator that became the first priority but it decreased the performance of the company. The indicator was the competitive price of the price variable. The strategy that could be applied to the price element was lowcost leader pricing. A leader in low-level pricing was not necessarily at the forefront volume (Sumarwan et al., 2009). This strategy could be performed by reducing production costs. PUSRI was planning to create a new factory that could replace three old factories. Replacing the three factories into one factory resulted in a reduction in human resources. After the construction of the new plant is completed, PUSRI employees would be retired in large numbers. The reduction of human resources and the reduction of production process would lead to a decrease in the selling price of fertilizer.

In the product element, differentiation strategy of quality aesthetics could be applied. In this strategy, producers are expected to create products by providing fit, finishing, and appearance of a product that are different from others (Sumarwan et al., 2009). The durability of fertilizer depended on the coating (coating the fertilizer granules with certain chemical compounds) in which the better the coating the better the durability of the fertilizer. The coating of PT PUSRI fertilizer used bentolite which had good durability but had a slightly expensive price of raw material. The alternative material that can be used other than bentolit was clay. Clay did not have long endurance like bentolit but it had cheaper price of raw material. Based on the research findings, it was found that the durability of PUSRI fertilizer was too excessive so it could be reduced by replacing it with clay. Clay material was easily destroyed so it would be easy for the farmers to use it while cultivating the crops. Another brand still used bentolit a lot. Clay use in PUSRI would provide an interesting difference.

\section{CONCLUSION AND SUGGESTIONS}

The performance of marketing mix of all indicators could still be improved. Based on the average value of the variables that must be improved from first to the end in sequence were: product, place, price and promotion. Factors of the marketing mix that significantly affected customer satisfaction of PT PUSRI fertilizer were product and price. Place and promotion factors had no significant effect on customer satisfaction. Meanwhile, customer satisfaction had significant effect in building customer loyalty. The level of customer satisfaction of PT PUSRI fertilizer was in the 'satisfied' category with a value of 67.8 percent. 
While the level of customer loyalty of PT PUSRI fertilizer was at the level of 'loyal' with a value of 64.51 percent.

Based on the evaluation results of the IPA diagram, the order of the main priority level of the improvement that should be carried out by PT PUSRI were (1) Competitive Price, (2) Performance, (3) Match-to-Quality Price, (4) Affordable Price, (5) Features, (6) Reliability, and (7) Durability. The key priority indicator was the competitive price. Improving the performance was by reducing the performance of features, reliability, and durability indicators. The indicator that should be maintained performance was performance. The managerial implication that could be performed was on the product element by implementing differentiation strategy of quality aesthetics. At the price element, low-cost leader pricing strategy could be conducted. The manufacture of the new factory could replace the three old factories.

Based on the above conclusions, there are several suggestions that can be given from this research, among others:

- The management of PT PUSRI is suggested to improve the performance of the variables that significantly affect customer satisfaction;

- Further research can analyze more deeply about the product and price indicators. Within these variables, there may still be other indicators that can be added;

- It is recommended to find new variables to further refine the next research.

\section{REFERENCES}

1. Cengiz E, Yayla HE. 2007. The Effect of Marketing Mix On Positive Word of Mouth Communication: Evidence From Accounting Offices in Turkey. Innovative Marketing. 3(4):73-86.

2. Iskandar AYS. 2017. Pengaruh Bauran Pemasaran Terhadap Kepuasan dan Loyalitas konsumen PT. Madu Pramuka [tesis]. Bogor (ID): Institut Pertanian Bogor.

3. Kotler P dan Keller KL. 2009. Manajemen Pemasaran. Edisi ke 13. Jilid 1. Diterjemahkan oleh: Bob Sabran. Jakarta (ID): Erlangga.

4. Muala AA dan Qurneh MA. 2012. Assesing the Relationship between Marketing Mix and Loyalty through Tourists Satisfaction in Jordan Curative Tourism. American Academic dan Scholarly Research Journal. 4(2):1-14.

5. Oghojafor BEA, Lapido KAP, Ighomereho OS, Odunewu AV. 2014. Determinants of Customer Satisfaction and Loyalty in the Nigerian Telecommunications Industry. British Journal of Marketing Studies. 2(5):67-83.

6. Praniti NLGWA, Parining N, Putra IGSAP. 2016. Strategi Pemasaran untuk Meningkatkan Penjualan Pupuk Organik (Studi Kasus pada Simantri 174 GAPOKTAN Dharma Pertiwi Kelurahan Lukluk, Kecamatan Mengwi, Kabupaten Badung). Jurnal Agribisnis dan Agrowisata. 1(1): 1-6.

7. Pyeong KK, Oh KY, Kweon LM, Kil YM. 2014. The Effects of Co-Brand Marketing Mix Strategies on Customer Satisfaction, Trust and Loyalty for Medium and Small Traders and Manufactures. Marketing and Trade Journal. 18(1):140-151.

8. Semuel H. 2006. Ekspektasi Pelanggan dan Aplikasi Bauran Pemasaran Terhadap Loyalitas Toko Modern dengan Kepuasan Pelanggan sebagai Intervening Studi Kasus Hypermarket Carrefour di Surabaya). Jurnal Manajemen Pemasaran.1(2):53-64.

9. Sudana W. 2005. Potensi dan prospek lahan rawa sebagai sumber produksi pertanian. Analisis Kebijakan Pertanian, 3: 141-151.

10. Sumarwan U, Djunaidi A, Aviliani, Singgih R, Sayono JA, Budidarmo RR, Rambe S. 2009. Pemasaran Strategik, Strategi Untuk Pertumbuhan Dalam Pemnciptaan Nilai Bagi Pemegang Saham. Jakarta Timur (ID): Inti Prima.

11. Wills B. 2009. The Business Case for Environmental sustainability (Green). [Internet]. [diunduh 20 agustus 2017]. Tersedia:http://www.leanandgreensummit.com/LGBC.pdf.

12. Zeithaml VA, Bitner MJ. 2000. Service marketing: integrating customer focus across firm second edition. New York (US): McGrow-Hill Education. 